grouad for a discussion which $\mathrm{I}$ cannot consider it proficable to costinue. WILLIAM B. CARP ENTER

\section{The Glacial Geology of Orkney and Shetland}

OWING to an accident $I$ did not see your number of September 13 containing my letter on the glacial geology of Orkney and Shetland and Prof. Geikie's article (vol. xvi. p. 414), until my return from Scotland a few days ago. Otherwise I should have troubled you sooner with a few observations thereon.

In the first place I wish to thank Prof. Geikie for the very courteous manner in which he has referred to the remarks of an outsider who has ventured to intrude on what the Professor has made, to such an extent, his own peculiar province.

In the next place I am glad to find that upon what was the most important fact in my statement, viz., the absence of ra'sed beaches or other signs of recent elevation of the land in Orkney, Prof. Geikie agrees with me.

I call this the most important because it bears directly on the theory of wide-spread changes in the relative level of sea and land owing to secular causes, such as a change in the axis of the earth's rotation, or in the position of its centre of gravity. If it can be proved that the difference of level, which caused the raised beaches of the south of Scotland, and extended north along the coast of Ross and Sutherland, dies out as we proceed further north, and disappears altogether in Orkney and Shetland, it is truly a crucial experiment which shows that these raised beaches are due to local elevations of the land, and not to a general sinking of the sea.

This is the conclusion to which Prof. Geikie points, though he naturally finds it difficult to unferstand why the uphexval, so marked in Sutherland, did not affect Caithness and Orkney.

I believe I can add a few facts which may assist in removing these doubts.

At one of the places in Caithness mentioned by Prof. Geikie, where the existence of a raised beach might be possible, viz., in the sheltered Bay, between Freswick and Wick, I beileve there is one, though less strongly marked and at a lower elevation than those in simlar situations in Sutherland. I allude to a terrace which bounds the links of Keiss Bay, about half a mile inland from the present coast-line. 1 cannot speak positively, not having seen it for some years; but my recollection is that it is a perfect miniature reproduction of the terraces round Brora and other bays in Sutherland. If so, it is a positive proof that the elevation of the land died out towards the north, and we might reasonably suppose that somewhere about the line of the Pentland Firth was the neutral axis, on one side of which the land rose, while on the other it fell.

Be this as it may, the fact is, I think, incontrovertible that Orkney did not share in the southern movement of elevation. This rests not only on the absence of raised beaches, forming terraces, which might possibly have disappeared, but still more on the absence of all traces of marine action, such as pebbles, sand, or shells, on the low plains which must have been submerged.

I would ask Prof. Geikie to consider whether the single instance of the Loch of Stennis is not conclusive. If the sea had ever stood twenty or thirty feet higher relatively to the land than it now does, the whole plain up to the hills must have been a sheltered, shallow, inland fiord.

As the land rose to its present level this must have left not only a terraced beach at the foot of the hills, which might possibly have disappeared (though it is hard to see why it should sive such a sheltered situation), but the whole have done so in such a sheltered situation), but the whole plain must have bells. These could not have disappeared, and as they are nowhere visible and the plain consists every where of the they are nowhere visible and the pock, with a thin mantle of resulting from its disintegratiun by ordinary atmospheric causes, I am, I think, justified in assuming it to be proved that Orkney did not share in the in assuming it to be proved which affected the rest of Scotland. recent movement of elevation which affected the rest of Scotland.

Now one word as to glaciation. I can assure Prof. Geikie that I do not think for a moment of setting my authotion he tells his, and that if he is right in the instances of glaciation he tells us he has observed in Orkney, so far from being disappointed, a perplexing anomaly.

Of course Orkney must have experienced the full rigour of the glacial period, and it is only natural to expect that it should show the same abundant signs of glaciation as the adjoining counties of Scotland. Prof, Geikie will therefore excuse me if
I still retain a little of that healthy scepticism which is so conducive to the establishment of truth, and venture to plead that judgment may be suspended until there is further evidence. I do so mainly because the Professor's own statement is that during his visits to Orkney his attention was devoted mainly to the old red sandstone, and his remarks on glaciation were only inciden'al. Now there are some proofs of glaciation which are so obvious that there can be no mistake about them, olhers which may easily be mistaken, and which require close examination by a practised eye directed specially to them, to arrive at a ju,t con. clusinn.

Boulders of foreign rock, perched blocks, rocks unmistakah'y rounded and polished by the ice plane, are among the foriner. But striæ require great practice and careful exami ation to be sure of them in a district of finely laminated sandstones which weather constantly into parallel lines or grooves. -tony clay a ain, from disintegrated rock, is o'ten so like boulder clay that it requires close observation to distinguish one from the other. And finally where steep hills have crumbled away and filled up many places in the narrow valleys between them with their débris, as at Hoy, the appearances are very like those of glacial moraines.

Now I observe that nearly all the conclusive proofs of glacial action are wanting in Prof. Geikie's enumeration. He has not seen, or heard of anyone who has seen, a single boulder or perched block, or even a single piece of foreign stone in Orkney.

As regards boulder-clay I would join issue on his instances, taking especially that of Kirkwall Bay, because it is typical of the other cases and so easily accessible that the facts can readily be verified.

I believe it to be disintegrated and not boulder clay, for the following reasons :-

I. The clay is not compact like that of genuine boulder-clay, but of looser structure, and often clearly mide up of minute splinters of the disintegrated rock.

2. The stones in the clay are never foreign stones, and are not scattered irregularly, as if shot out into a huge rubbish heap, as in true boulder-clay, but arranged for the most part so that the original lines of stratification can be followed.

3. If the section which resembles boulder-clay be followed up, it will be found to merge insensibly in what is unmistakably the common disintegrated surface soil of the district.

There only remains the question of roches moutonnées, and here I speak with the greatest diffidence, for certainly Prof. Geikie ought to know a great deal better than I whether a hummock of rock is or is not "admirably ice-worn and striated" like those behind Stromness.

I can only say that I have looked at them often, and they appear to me to be very different from the roches moutonnés of which I have seen so many in Scotland, Wales, and Swirzerland. They are not rounded, smooth, and polished, as if planed into shape by some gigantic tool, but simply irregular hummocks of rock, sometimes smooth and sometime rough, according to accidents in the bedding and weathering of the strata. So at least they seem to me, and even in the valleys of Hoy, where, if anywhere, there were local glaciers, the sections shown by the small streams and low coast-line, always, I believe, exhibit the same appearance of sandstone strata, coming at an angle to the surface, and with their edges not planed off, but passing gradually into surface soil by disintegration.

Of course I make these statements subject to correction. It may he that I have failed to see things because my eye is not sufficiently educated. But when we couple what is, I believe, absolutely certain, viz., the absence of the more prominent and cbvious proofs of glaciation in the form of boulders and foreign rocks, with the equally certain fact that Oikney was an exception to the general rule of recent elevation, I thiuk Prof. Geikie wil admit that the interests of science will be promoted by any remarks which miy lead to reasonable doubts, and theretore to conclusive investigation, as to the fact whether Orkney does or does not give proof o? having been covered by a great polar icesheet duriug the g'acial period.

36, Wilion Crescent, S. W.

\section{Explosions}

I HAVE been waiting to see if Mr. Galloway's paper on "Explosions in Mines" published in Nature, vol, xvil. p. 21, would lead to any correspondence. Your readers may be interested in an incident reported to me by the late Dr. Böttinger, of Messrs, Allsopp's brewery, Burton-on-Trient, 